\title{
PENGEMBANGAN MOTIF BATIK BONDOWOSO SEBAGAI EKSPRESI AKULTURASI BUDAYA
}

\author{
H. A. Tutut Subadyo \\ Fakultas Teknik Universitas Merdeka Malang
}

\begin{abstract}
Abstrak
Seni batik merupakan warisan budaya lokal yang menyimpan pengetahuan serta kearifan lokal yang tinggi nilainya. Dengan kata lain batik adalah kerajinan yang memiliki nilai seni tinggi dan sejak lama telah menjadi bagian dari budaya Indonesia. Oleh karena itu batik Bondowoso termasuk salah satu warisan budaya yang perlu dilestarikan, dilindungi dan didukung pengembangannya. Pengabdian ini mencoba mengembangkan design motif batik Bondowoso sebagai hasil akulturasi budaya masyarakatnya (Jawa - Madura), sehingga dapat menjadi asset untuk cultural heritage. Fokus dan prioritas pengembangan design motif bertolak dari permasalahan masih minimnya ragam hias yang telah ada. Untuk itu dalam kegaiatan pengabdian tersebut dilakukan pembekalan dan pelatihan kepada calon designer dari mitra (Sumbersari - Maesan) guna mengembangkan jenis-jenis motif batik Bondowoso (kontemporer, vernacular,dan tradisi konvensional) dengan sandaran pada eksplorasi potensi budaya dan lingkungan bentang alamnya.
\end{abstract}

Kata Kunci : batik, bondowoso, budaya, design, motif

\section{PENDAHULUAN}

Kabupaten Bondowoso memiliki potensi kerajinan batik yang telah dikenal oleh masyarakat luas sejak lama yang merupakan warisan budaya nenek moyang. Pada awalnya batik merupakan produk seni, kemudian berkembang lebih luas lagi menjadi produk sandang yang memiliki nilai seni. Di Desa Sumbersari dan Maesan, Kabupaten Bondowoso terdapat motif batik klasik dan modern. Genre batik ini pada dasarnya adalah batik yang tumbuh dan berkembang sesuai dengan dinamika kebudayaan dan peradaban masyarakatnya. Motif batik yang dibuat oleh para pengrajin di Sumbersari dan Maesan, Kabupaten Bondowoso sangat dipengaruhi oleh kondisi lingkungan, seperti lingkungan alam dan keadaan flora dan fauna. Setiap goresan dalam motif batik memiliki makna yang tinggi berupa filosofi- filosofi hidup antara lingkungan dengan masyarakat maupun hubungan antara manusia dengan Tuhan Yang Maha Esa. Motif batik Bondowoso menunjukkan adanya pengaruh budaya Jawa, dan Madura. Hal ini tampak pada bentuk hiasan yang menbidang, seperti lukisan ragam hiasnya. Dengan berkembangnya kerajinan batik di di Sumbersari dan Maesan, maka daerah tersebut pada saat ini dijadikan sebagai salah satu tujuan wisata bagi wisatawan domestik maupun wisatawan dari mancanegara yang berkunjung ke Bondowoso.

\section{METODE KEGIATAN}

\subsection{Penentuan Permasalahan dan Prioritas}

Penentuan permasalahan dan prioritas program IbM dilakukan atas kerjasama antara tim IbM dengan mitra yaitu pengusaha batik tulis Sumbersari dan batik tulis Maesan, di Kabupaten Bondowoso. Sehingga seluruh kegiatan, mulai dari pembuatan proposal, penentuan permasalahan dan prioritas serta perencanaan variabel permasalahan hingga langkah-langkah menuju solusi pelaksanaan dalam program ini dilaksanakan secara bersamasama antara tim IbM dengan kedua mitra tersebut.

\subsection{Metode Pendekatan untuk Menyelesai- kan Masalah}

Untuk menyelesaikan masalah yang dihadapi oleh mitra dilakukan sebuah action research, dimana variabelnya adalah: (a) design development produktivitas, (b) diversifikasi produk dan peningkatan kinerja produktivitas, (c) intervensi perluasan pemasaran. Variabel tersebut didata sebelum IbM, kemudian variabel yang sama diberlakukan ketika aplikasi baru telah dilakukan. Dengan hasil riset yang cukup positif dan signifikan, maka aspek-aspek yang menjadi variabel IbM ini 
merupakan kunci keberhasilan dalam pengembangan usaha mitra.

\subsection{Tahapan Kegiatan}

Tahapan kegiatan dalam program IbM ini menunjukkan langkah-langkah solusi atas persoalan yang disepakati bersama yakni sebagai berikut:

- Pengenalan masalah Tim IbM mencari informasi tentang masalah yang dialami oleh mitra 1 (batik tulis Sumbersari) dan mitra 2 (batik tulis Maesan), berkaitan dengan peningkatan kualitas desain, produktivitas, dan perluasan pemasaran.

- Usulan peningkatan kualitas desain, peningkatan produktivitas dan diversifikasi produk, pengembangan dan perluasan pemasaran melalui ekshibisi - promosi.

Tim IbM membuat usulan, mendiskusikan dan menyepakati program peningkatan kualitas desain, produktivitas dan diversifikasi produk, pengembangan dan perluasan pemasaran, berupa pelatihan dasar desain dengan ekplorasi dan elaborasi berbagai motif flora endemik maupun diversifikasi dan peningkatan produksi serta intervensi pengembangan pemasarannya.

- Pelaksanaan IbM

- Tim IbM bersama Mitra 1 (batik tulis Sumbersari) dan Mitra 2 (batik tulis Maesan) melaksanakan kegiatan IbM di masing-masing lokasi mitra sesuai dengan rencana kerja yang telah disepakati bersama.

- Evaluasi

- Tim IbM bersama Mitra 1 (batik tulis Sumbersari) dan Mitra 2 (batik tulis Maesan) melakukan evaluasi terhadap kegiatan IbM.

\section{HASIL DAN PEMBAHASAN}

\section{Pengembangan Motif Batik Bondowoso : Akulturasi Budaya Jawa - Madura}

Batik Bondowoso motifnya dieksplorasi bukan cuma untuk memeragakan keindahan, melainkan juga cerminan watak yang memunculkan warnawarna ceria, berani, dan tegas. Berevolusi lewat adukan budaya Jawa, dan Madura, batik Bondowoso didorong untuk mencerminkan karakter dinamis, egaliter, semi pragmatis, sekaligus ungkapan keinginan untuk eksis dan tampil berkarakter mengeksplorasi bentang alamnya yang indah.

Motif tersebut biasanya dibuat atas dasar bentuk-bentuk alam seperti tumbuhan, manusia, hewan, benda mati (misalnya, tumbuhan, pegunungan, panorama alam, dan bangunan) dan sebagainya. Selain itu, para desainer dan calon desainer peserta pelatihan mendesain motif diajari bisa menjelaskan atau mengungkapkan pengalamannya atau pengalaman estetik desainer dan calon desainer. Eksplorasi motif dapat diambil dari berbagai sumber referensial, yaitu: (1) tanaman, hewan, manusia, gunung, air, awan, matahari, bulan, bintang, dan sebagainya; (2) simbol atau dewa, atribut atau mereka yang berkuasa dalam bentuk senjata, takhta, pengaturan huruf, dan sebagainya; (3) bentuk bentuk imajiner manusia; dan (4) bentuk-bentuk geometris seperti lingkaran, segitiga, kotak, dan sebagainya.

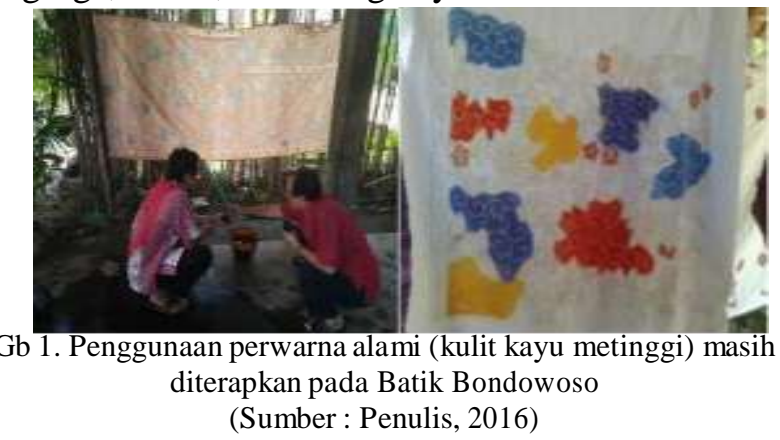

Kesukaan terhadap warna menjadi refleksi dari unsur budaya lokal Bondowoso yang sangat menjunjung tinggi harga diri, dan memunculkan ketegasan watak, dijadian ancangan dalam pengembangan desain motif batiknya dalam pelatihan ini. Tegas diartikan mengandung makna perilaku memegang prinsip yang diyakini sehingga tidak terombang-ambing. Dalam pemilihan warna, misalnya hampir selalu warna yang bernuansa tegas, karena masyarakat Bondowoso (Jawa dan Madura : Jawara) hanya mengenal rasa manis dan asin, bahkan ketika membangun rumah, posisinya harus mengarah pada arah mata angin utama.

Meskipun bersetia pada tradisi batik tulis, tak ada motif baku di antara para perancang dan pembatik (batik tulis Sumbersari dan batik tulis Maesan) di Bondowoso. Oleh karena itu selain motif klasik yang sesekali masih dikukuhi, setiap pembatik didorong untuk rajin mengeluarkan ekspresi desain sendiri, danditargetkan setiap kurun tiga-enam bulan.

Ekspresif dan tegasnya motif-motif yang diintrodusirkan kepada para desainer dan calon desainer pembatik dari Sumbersari dan Maesan di Kecamatan Maesan Kabupaten Bondowoso, mengungkapkan lewat produktivitasnya dimana setiap pekan mampu menghasilkan 15 - 20 lembar batik tulis yang dihasilkan dari motif 
malam. Watak ekspresif (batik tulis Sumbersari dan batik tulis Maesan) Bondowoso dalam pengembangan desain dimaksudkan untuk menciptakan dan memunculkan komposisi motif dan warna yang tegas pada kain batiknya, meskipun tidak sepresisi seperti batik Jawa. Itulah yang ditargetkan menjadi sisi keunggulan batik tulis Bondowoso, dimana satu sama lain ditampilkan beda untuk masuk kategori limited edition, sehingga tampil bukan pasaran. Tingginya pamor limited edition merupakan ekspresi ingin menunjukkan bahwa dirinya ada.
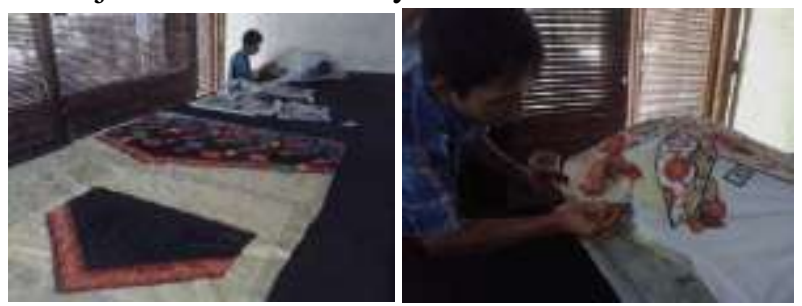

Gb 2. Teknik coletan/dulitan yang dilakukan pada Batik Bondowoso (Sumber : Penulis, 2016)

Menciptakan sesuatu yang berbeda dengan yang sudah ada (kemarin dan sekarang) menjadi tuntutan kreatif. Kebebasan itu harus menjadi sesuatu keniscayaan buat orang yang berpikir bahwa Bondowoso adalah kota kecil dan merupakan daerah agraris tadah hujan. Dengan demikian batik Bondowoso harus merembes dan menjelma menjadi produk budaya yang perlu dilestarikan (culturtal heritage) sekaligus menjadi produk budaya masyarakat kebanyakan.

Motif batik yang dieksplorasi dipertautkan dengan kondisi lingkungan, seperti lingkungan kultural masyarakatnya (Jawa, dan Madura) dan lingkungan bentang alam lembah gunung Ijen dan kekayaan flora dan faunanya. Setiap goresan dalam motif batik yang didesiminasikan diberi makna yang tinggi berupa filosofi- filosofi hidup antara lingkungan dengan masyarakat maupun hubungan antara manusia dengan Tuhan Yang Maha Esa

Eksplorasi idea kreatif motif batik tulis Bondowoso diekspresikan dengan memperhatikan adanya pengaruh dan akulturasi budaya Jawa, dan Madura. Hal ini diperlihatkan pada bentuk hiasan yang membidang, seperti lukisan ragam hias yang didesain dengan corak kondisi alam di lingkungan masyarakat agraris-agamis maupun kondisi bentang alam, merupakan kondisi dua lingkungan yang saling menunjang.

Budaya lokalnya khas dan kuat karena terisolasi lingkungan alamiahnya, justru mampu berstrategi untuk mempertahankan tradisi. Bentang alamnya dilingkung dua gunung: Ijen dan Raung menjadikan masyarakat Bondowoso sangat sinkretistis namun terbuka menerima budaya luar menjadi asset untuk pengeksplorasian motif baru yang diintrodusir tentang potensi lingkungan alam lokal (khususnya flora endemik : singkong, tembakau, tape, dan lain-lain), karakter dan kultur masyarakat yang membentuk komunitas masyarakat Bondowoso (Jawa - Madura : Jawara) sebagai referensi untuk melakukan penelusuran, penjelajahan, kontemplasi, eksplorasi, dan elaborasi, dan diakhiri dengan penorehan sketsa hasil stilasi berbagai potensi tersebut ke dalam sebuah motif maupun pola desain baik yang bersifat konvensional, kontemporer, vernakular, maupun modernistik.

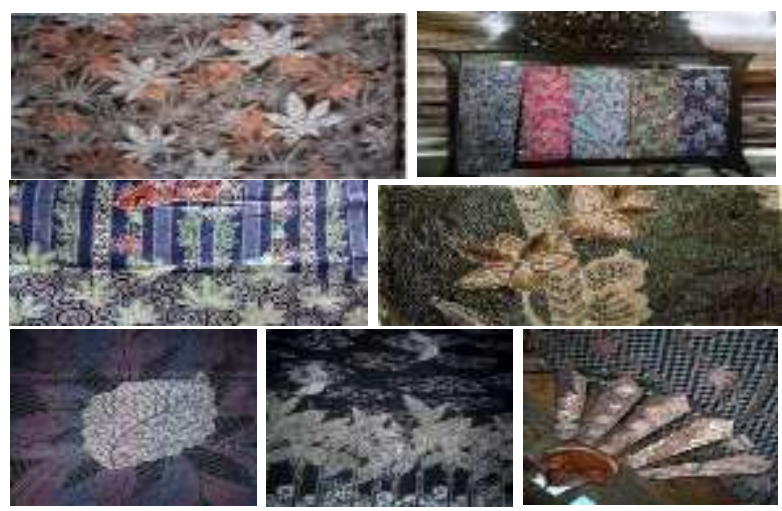

$\mathrm{Gb}$ 3. Hasil pengembangan desain motif untuk batik tulis Bondowoso berbasis flora endemik (daun singkong dan tembakau) (Sumber : Penulis, 2016)

Batik tulis Sumbersari dan batik tulis Maesan saat ini telah berkembang pesat ke wilayah “ tapal kuda" ( Kabupaten Situbondo, Jember, Banyuwangi, Lumajang, Probolinggo, Pasuruan) bahkan ke Malang, Surabaya, Bali, dan Jakarta. Kegiatan ini telah menjadi usaha pokok bagi sebagian masyarakat di daerah tersebut. Dengan berkembangnya (batik tulis Sumbersari dan batik tulis Maesan), maka Kecamatan Maesan, pada saat ini telah dijadikan sebagai salah satu tujuan wisata bagi wisatawan domestik maupun mancanegara.

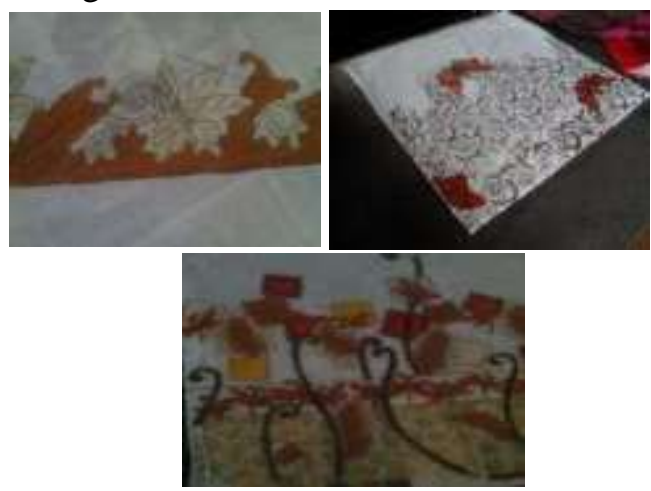

$\mathrm{Gb}$ 4. Hasil desain motif kontemporer melalui eksplorasi flora (daun tembakau) pada programIbM di batik tulis Sumbersari dan Maesan Bondowoso (Sumber : Penulis, 2016) 

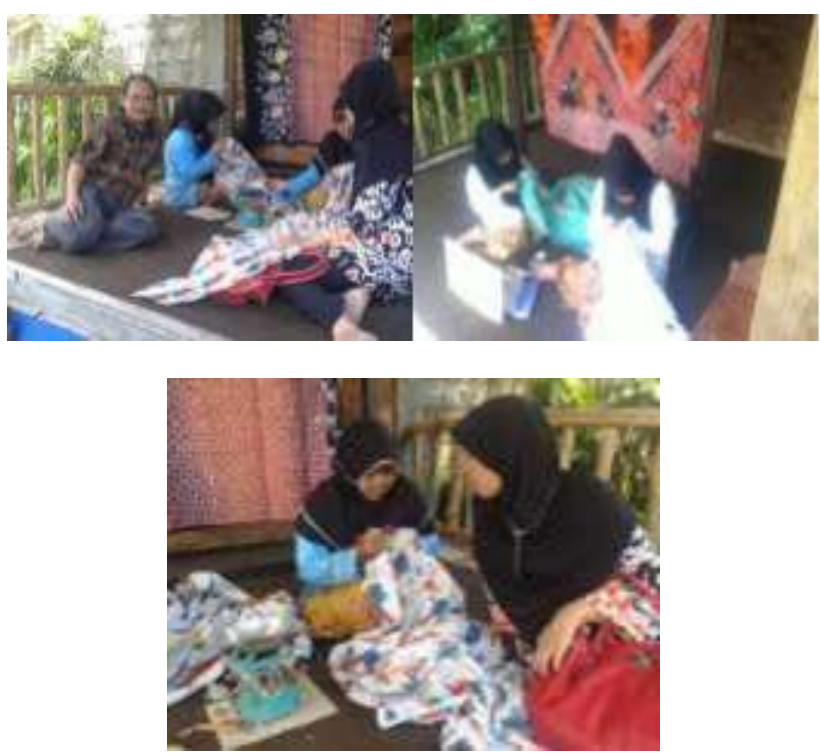

$\mathrm{Gb}$ 5. Implementasi hasil pengembangan desain motif vernakular dan kontemporer oleh para pembatik pada program IbM di batik tulis Sumbersari dan

Motif batik yang dieksplorasi juga diperoleh dari budaya yang tumbuh dan kembang di masyarakat Bondowoso. Kebudayaan yang mentradisi di wilayah ini jauh dari produk budaya bangsawan atau priyayi. Kantong kebudayaan Bondowoso memang tersembunyi dibalik deretan Gunung Ijen dan Gunung Raung, menjadikan budaya lokalnya kuat. Dengan keterbukaannya batik Bondowoso terhadap perwajahan baru warna dan motif, memperagakan watak dan karakter masyarakat Bondowoso.

Bertolak dari keinginan utuk berbeda dengan batik klasik dari Jawa maupun Madura, motif batik kontemporer Bondowoso dikembangkan dengan meramu ekletistik sehingga menampilkan warna-warna yang semarak. Demikian halnya dengan namanyapun menjadi bebas sesuai kreasi baru yang bisa digali dari lingkungan sekitar. Bahkan sentuhan motif klasik juga dicoba diterapkan atau digunakan untuk produk-produk non busana seperti dasi, jilbab, sajadah, dompet, tas, sandal, dan lain-lain.

Tanpa terbelenggu pakem tradisional motif batik di Bondowoso diakselerasi dengan mengadopsi langgam batik yang bertumbuh di sekitar wilayah tapal kuda maupun Madura, termasuk mengintrodusir pemilihan warna merah, hijau, dan biru, yang dipadu dengan warna tegas yang mendominasi dimensi ruang dan detail dekoratif yang rumit.
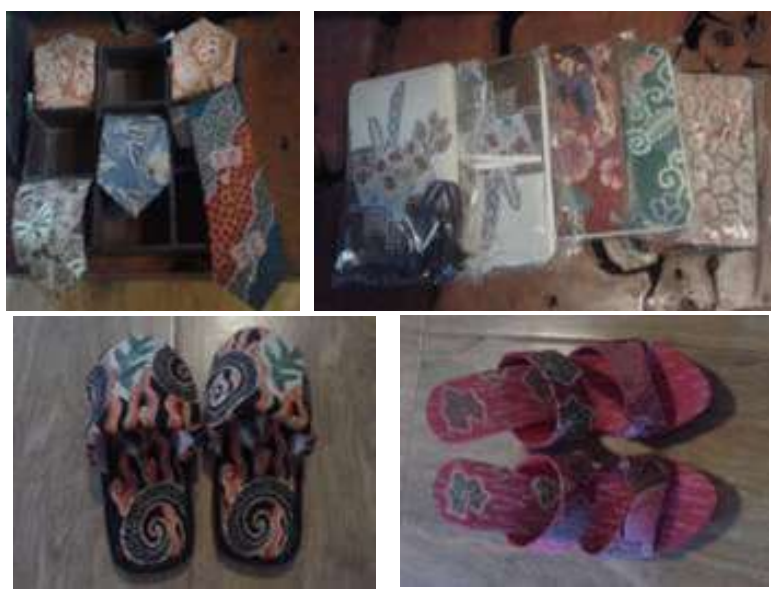

Gb 6. Diversifikasi produk (dasi, dompet, sepatu, sandal) dengan desain motif batik Bondowoso dalam program IbM Unmer Malang (Sumber : Penulis, 2016).
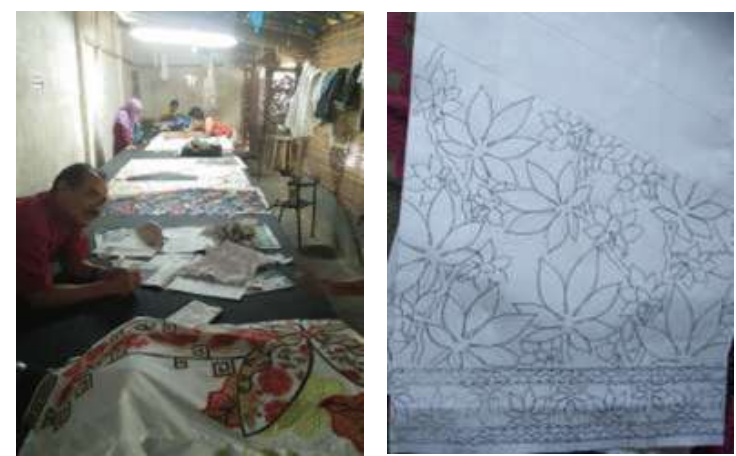

Gb. 7. Hasil pelatihan pengembangan desain motif batik pada mitra IbM Unmer Malang di ruang produksi 'colet/dulit' sebelum kegiatan 'isen-isen' dan salah satu hasilnya pada produk 'limited edition' (Sumber : Penulis, 2016).

\section{Mempromosikan Batik Bondowoso}

Salah satu persoalan yang dihadapi oleh para pengusaha atau pengrajin batik adalah gempuran kain tekstil bermotif batik yang popular disebut "batik printing". Sayangnya, kehadiran tekstil bermotif batik itu belum dianggap ancaman serius bagi keberadaan batik tulis oleh pemerintah. Pengusaha dan pembatik di Bondowoso menengarai hal itu dari pengalaman mereka di ajang pameran, baik di tingkat regional maupun nasional. Persoalan lain yang sering menaungi adalah manajemen penjualan dan desain motif yang masih terbatas serta diversifikasi produknya belum kaya. Sistem "jual murah" agar bisa membawa pulang sejumlah uang yang dilakukan saat pameran - ekshibisi seyogyanya secara perlahan dihindari. Perilaku seperti itulah yang membuat harga pasaran batik di Bondowoso secara umum kurang menguntungkan di mata konsumen. 


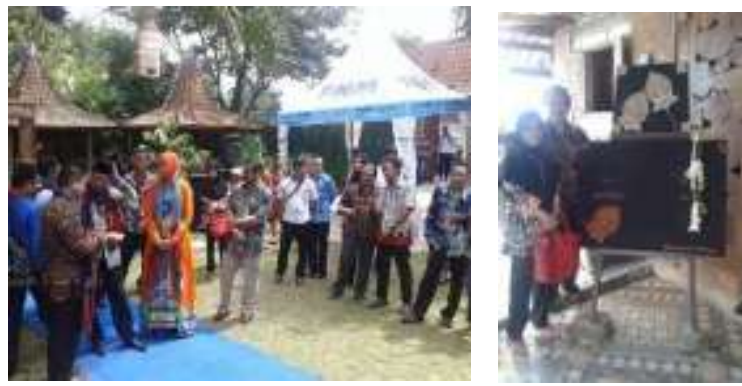

Gb. 8. Pembukaan/peresmian pameran batik Sumbersari \& Maesan, Bondowoso oleh Bupati Bondowoso (Drs. H. Amin Said Husni), Bupati Jember (dr. Hj. Faida, MMR), Wakil Ketua

Komisi VI DPR RI (Drs. H. Azam A Natawijaya), dan Duta Besar Kolombia (Mr. H.E. Alfonso Garzon Mender) bekerjasama dengan Direktur Keuangan PT. PNM (Sumber : Penulis, 2016)
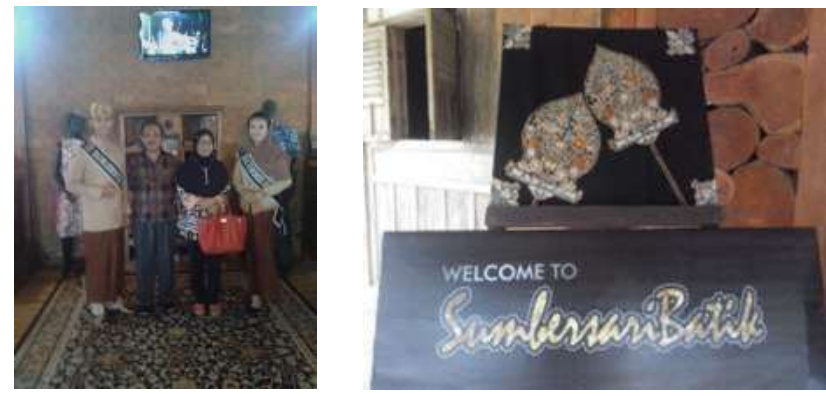

Gb. 9. Promosi dan pameran batik Sumbersari \& Maesan, Bondowoso dimeriahkan dengan event pemilihan Kacong \& Jebing Kabupaten Bondowoso tahun 2016

(Sumber : Penulis, 2016)

Oleh karenanya, langkah utama yang seyogyanya dilakukan adalah berbagi pemahaman diantara para pembatik/desainer akan nilai adiluhung yang terkandung dalam batik tulis. Batik tak sekedar melulu tentang motif, warna, dan harga. Dalam selembar kain batik tulis tertuang karya kreativitas dan ketrampilan tangan pembatik. Mereka akan terus membatik meskipun karyanya dihargai rendah. Namun, membeli selembar kain batik tulis dengan harga pantas berarti mengapresiasi budaya dan menopang hidup banyak orang.

Pada kegiatan ekshibisi - pameran - promosi tersebut juga ditampilkan peragaan busana yang menggunakan batik sebagai master show nya. Para peragawan dan peragawati serta komunitasnya didukung oleh mereka-mereka yang sangat berpengalaman dalam kegiatan Jember Fashion Carnaval (JCF) yang sudah mendunia. Peragaan busana tersebut menghadirkan koleksi busana siap pakai dalam 24 tampilan. Sekalipun kesan yang tampil serba rileks, namun karakter chic nan elegan, khas batik Bondowoso senantiasa menonjol, seperti dalam koleksi jaket, side dress, gaun panjang, kemeja, blus, rok lebar, dan lain-lain

Balutan batik Bondowoso, yang ditampilkan bernuanasa tropik menjadi salah satu elemen fashion yang digarap cantik dan bernuanasa santai. Injeksi budaya pop anak muda dalam koleksi ini menguatkan atmosfer bernuanasa tropik khas nusantara yang serba terbuka dan hangat, serta ramah. Tampilan lain memadukan kesan sopan dengan sentuhan feminim - agamis, seperti rok lebar berpadu blazer dengan dalaman kemeja yang dilengkapi dasi pendek, dan gaun panjang, yang dipadupadankan dengan jilbab dengan asesorisnya tampil menonjol. Industri gaya hidup yang diperagakan dalam event ini sengaja diromantisasi sebagai elemen estetik yang fashionable, dimana acara ini hadir di daerah pedalaman yang masih menjunjung tinggi kesetaraan sosial - religius dan tidak materialistis - hedonistis.

Peragaan busana dalam agenda pelaksanaan IbM Unmer Malang ini, beserta perhelatan peresmian sanggar batik Sumbersari tersebut, membawa suasana yang akrab dan memberi ruang bagi masyarakat kebanyakan menjadi agenda publik yang penuh nuanasa lokalitas dan etnik. Perhelatan peragaan busana dalam acara tersebut berlangsung sebagai media publik, dan menciptakan kondisi non segregasi, sehingga antara kami dan mereka melebur menjadi satu. Pemilihan lokasi di tempat mitra satu (batik tulis Sumbersari) disengaja untuk memberikan kesempatan bagi masyarakat untuk bisa menyaksikan secara langsung tanpa dibatasi barikade aparat keamanan. Dalam hal ini sengaja diminimalisir suasana glamour dan snobisme yang selama ini melekat dalam dunia mode.

Dunia mode memang memiliki kekuatan laten dalam mencerna trend tersendiri. Oleh karena itu kegiatan ini merupakan respon yang cerdik untuk dieskploitasi, dalam rangka mengapresiasikan batik Bondowoso kepada masyarakat luas dan menginvasi pasar nasional dan internasional. Perhelatan peragaan busana batik Bondowoso ini dilaksanakan di ruang luar (halaman) dalam tapak diantara massa bangunan dari komplek batik tulis Sumbersari yang bersuasana asri dan rural yang disulap menjadi landas peraga (runway - cat walk) sepanjang 20 meter. Tapak yang diisi dan dibingkai sejumlah fasilitas bangunan bergaya tradisional Jawa Madura (sanggar, gazebo, warung makan, ruang pertemuan, rumah produksi, dan lainlain) menginsipirasi atmosfer kearifan lokal yang sangat kaya. Event ini selanjutnya disepakati untuk 
dijadikan satu kesatuan dengan event Jember Fashion Carnaval (JFC) di Jember yang sudah terlebih dahulu mendunia.

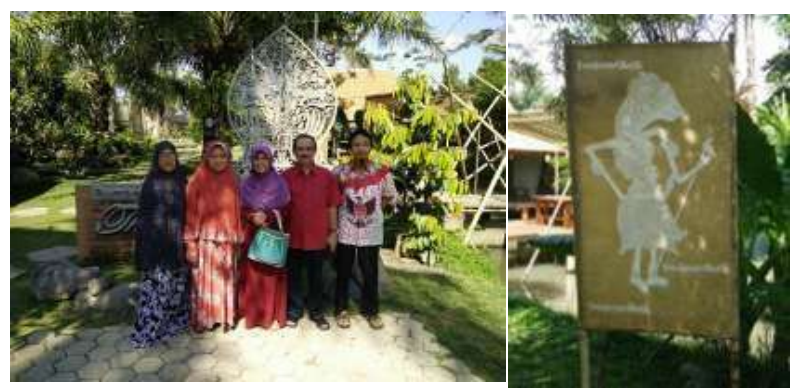

Gb 10. Diversifikasi usaha mitra IbM yang menopang perwujudan Batik Bondowoso sebagai asset Cultural Heritage (Sumber : Penulis, 2016)

\section{KESIMPULAN}

Pengembangan Design Batik Bondowoso sebagai cultural heritage dapat terlaksana jika eksplorasi terhadap nilai-nilai kearifan lokal (budaya : Jawa dan Madura; bentang alam : panorama pegunungan Ijen dan Raung; serta biodiversitas flora fauna endemik) menjadi sumber inspirasi dan kreatifitas penemuan motif-motif dengan beraneka langgam (konvensional, vernakular, kontemporer, modernistik), serta pendampingan ekshibisi promosi dan pameran karya - produk seni kriya batik.

Langkah konkrit yang penting dilakukan oleh pelaku pengrajin batik di Bondowoso dalam rangka pengembangan usahanya dengan : (1) mempertahankan motif dan warna klasik batik Bondowoso; (2) memperkaya desain dan motif dengan pewarnaan alami maupun sintetis; (3) meningkatkan dan menjaga kualitas dengan berbagai pelatihan; (4) memberi kesempatan pebatik/desainer dan tenaga lainnya ikut pelatihan dan melakukan diversifikasi usaha; (5) memperluas jaringan dan jejaring pengrajin batik untuk ikut ekshibisi-pameran - promosi serta menjaga relasi dengan para pemangku kepentingan; (6) regenerasi desainer dan usahawan batik berbasis keluarga dan komunitas paguyuban/koperasi; (7) memberi upah yang layak bagi para pekerja/pengrajin batik; dan (8) memberi kesempatan dan tempat bagi masyarakat belajar membatik.

\section{DAFTAR PUSTAKA}

Budi, Triton P. 2007. Panduan Sikap dan Perilaku Entrepreneurship. Yogyakarta: Tugu Publisher.

Camaro, Angky. 2008. UKM Sikecil Menggeliat di Tengah Badai. Malang: UMM Press. Institut

Javanologi LPPM UNS. (2012). Seminar Nasional, Lomba Desain, dan Peragaan Busana Lurik:

2012 Surakarta: http://lnstitute-javanologi lppm.uns.ac.id.

Junus, E (2003). Aspek Hukum dalam Sengketa Hak Kekayaan Intelektual Teori dan Praktek. Website: umum.kompasiana.com/ ...hki.

Kienan, Brenda. 2001. E-commerce untuk Perusahaan Kecil. Frans Kowa (pent.) Jakarta: PT Elex Media Komputindo.

Laksono, GB. (2009). Pengaruh Kebijakan Diversifikasi Produk Terhadap Profitabilitas (PadaPerusahaan Rokok Santje di Kabupaten Trenggalek). Malang: Thesis UMM. Meredith, Geoffrey G. Et al. 2000. Kewirausahaan: Teori dan Praktek. Andre Asparsayogi (pent.). Jakarta: Pustaka Binaman Pressindo.

Musnandar, A. (2012). "Peran UKM dalam Pertumbuhan Ekonomi Bangsa". "vailable in:http;//www.uin-malang.ac.id/

index.php?option =com content $\&$ view= article\&id =2883: peran-ukm-dalampertumbuhan-ekonomi-

Sriana, J. (2010). "Strategi Pengembangan Usaha Kecil dan Menengah UKM): Studi Kasus DiKabupaten Bantul", Prosiding Simposium Nasional 2010: Menuju Purworejo Dinamis dan Kreatif.

Sulistyastuti, D.R "Dinamika Usaha Kecil Dan Menengah (UKM) Analisis Konsentrasi Regional UKM di Indonesia 1999-2001". Jurnal Ekonomi Pembangunan. 9 (2), Desember 2005 Hal. 143-144.

Suryana. 2006. Kewirausahaan, Pedoman Praktis: Kiat dan Proses Menuju Sukses. Jakarta: Salemba Empat

Triyanto. (2011). Pemanfaatan HKI bagi UMKM di Kabupaten Karanganyar. Surakarta: Puslitbang HKI LPPM UNS.

Tulus Tambunan. (2010). "Apakah Kebijakan Pengembangan Usaha Kecil Dan Menengah Di Indonesia Selama ini Efektif", Makalah Workshop. BPPT, 8 April 2010.

Winansih E. 2013. Buku Ajar. Estetika Bentuk. Jurusan Teknik Arsitektur, Fakultas Teknik, Universitas Merdeka Malang. 